\title{
DEVELOPMENT OF THEOLOGICAL TRAINING AND HERMENEUTICS IN PENTECOSTALISM: A HISTORICAL PERSPECTIVE AND ANALYSIS
}

\section{Marius Nel}

Research Unit of the Faculty of Theology, North-West University nel.marius1@gmail.com

\section{ABSTRACT}

The article hypothesises that the historical development of Pentecostal hermeneutics is closely related to and illustrated by Pentecostals' attitude towards theological training. A short survey is given of the development of theological training within the Pentecostal movement in order to demonstrate how it accompanied a change in the way the Bible was considered during the past century in terms of three phases. For the first three decades Pentecostals had no inclination towards any theological training; they considered that the Bible provided all they needed to know and what was important was not what people in biblical times experienced with or stated about God, but the way these narratives indicate contemporary believers to an encounter with God themselves, resulting in similar experiences. From the 1940s, Pentecostals for several reasons sought acceptance and approval and entered into partnerships with evangelicals, leading to their acceptance of evangelicals' way of reading the Bible in a fundamentalist-literalist way. From the 1970s they established theological colleges and seminaries where theologians consciously developed Pentecostal hermeneutics in affinity with early Pentecostal hermeneutics, although most Pentecostals still read the Bible in a fundamentalist-literalistic way - as do the evangelicals. Its hermeneutics determined its anti-intellectual stance and the way Pentecostals arranged the training of its pastors. The history of the Pentecostal movement cannot be understood properly without realising the close connection between its hermeneutics and its view of theological training.

Keywords: Pentecostal; hermeneutics; theological training; fundamentalism; literalism; evangelicals

\section{UNISA $\cong$}

Studia Historiae Ecclesiasticae Volume 42 | Number 2 | 2016 | pp. 191-207 https://upjournals.co.za/index.php/SHE 


\section{INTRODUCTION}

Although Pentecostals traditionally argue that their origins could be traced to the first-century apostles of Christ, the modern-day Pentecostal movement finds its roots in the last part of the nineteenth century. Charles Fox Parham prescribed only the Bible to instruct his students in his Bethel Bible College in Topeka, Kansas (McClung 2012, 5-6). He assigned them to find scriptural evidence for the baptism in the Spirit, leading to Agnes Oznam, one of the students, to speak in an unknown tongue on the significant date of 1 January 1901. The group interpreted glossolalia as 'initial evidence' of the baptism with the Holy Spirit as their study of the New Testament revealed, a sign of the imminent parousia (Chandomba 2007, 15-17; Synan 1997, 89-92).

Parham eventually established another Bible school in Houston, Texas, where William Seymour studied for a short while before his ministry led to the Azusa Street revival of 1906 at the Apostolic Faith Gospel Mission in Los Angeles (Burger 1987, 79; Synan 1971, 95-116; 1997, 92-95). Azusa Street became an important spiritual centre where thousands experienced the baptism with the Spirit and some took the message of Pentecost to other parts of the world, including South Africa (Melton 2016, 1). The Pentecostal movement was born partly from a perception of - and as a reaction to - the established church with its high view of formalistic worship services led by pastors with sound theological training, leading churches providing for socially significant people, which preclude the poor and illiterate.

\section{DEVELOPMENT OF THEOLOGICAL TRAINING IN THE PENTECOSTAL MOVEMENT}

A considerable proportion of the early Pentecostals were either illiterate or theologically illiterate; a group that felt excluded from and disinherited by the established churches (Anderson 1979, 77), leading to feelings of hostility and aggressiveness among Pentecostals and their studied rejection of the world (Anderson 1979, 195). The early membership of Pentecostal assemblies did not consist of professional people; peasants, artisans and labourers along with other poor people constituted the members of the new movement and its leaders (Hunter 2013, 2-3).

In their perception it was theological scholarship within the Protestant churches that caused their formalism, deadliness and captivity to 'theologians', in contrast to the Pentecostal movement where all believers had received the Spirit and enjoyed his guidance (Letson 2007, 115). The early Pentecostal movement was characterised by a deep animosity towards any kind of professional theological training (Hayford 2006, 16) or even any other kind of training as most of the members were not educated themselves and did not value further education. The reason for this is twofold. On the one hand Pentecostals believed that they need no other equipment because Jesus promised that the Spirit would give believers the words they might need to defend 
themselves (Matt 10:19), a promise that has been made valid for all believers with the outpouring of the Spirit and that democratised the liturgy and decision making in the Pentecostal movement. They only need the Bible and the anointing of the Spirit that enables them to understand Scriptures (Menzies 2010, 38-39). Theological knowledge is not only unnecessary (Erasmus 1996, 13) but actually harmful and even dangerous for a Spirit-filled Christian because in their experience theology undermined many believers' (naïve) belief in God (Van der Spuy 1985, 107). On the other hand, Pentecostals expected the King to come back imminently; there was not time to waste in acquiring theological knowledge when every moment should rather be spent spreading the gospel of Pentecost (Whitehouse 1953, 67). Their imminent eschatological expectation determined also early Pentecostals' attitude toward the community, of withdrawal from social concerns and preoccupation with personal pietism (Anderson 1979, 199).

In the early days, Pentecostals would start prayer meetings in their homes, inviting neighbours, friends and families. These meetings eventually led to the formation of churches where every believer was responsible for the welfare of the assembly. A leader should not first meet certain requirements of training before taking the lead; there were no constituted churches that could regulate the ministry. The assembly was viewed as the body of Christ, the place where he is present and the instrument through which he lives and works (Langerman 1983, 124). Believers shared in the priesthood and prophethood by participating in every aspect of assembly life, including the worship service (Garrard 2009, 92; Stronstad 1999, 60-65). Everyone was expected to be involved in witnessing, preaching, singing and worshiping, praying, and caring for the needy and sick. At first no one ministered in a full-time capacity; every member was held responsible for caring for the church. Anyone who felt the anointing and tugging of the Spirit could preach and all who were born again, witnessed of their faith (Burger 1987, 181). In time, Pentecostal denominations were organised and members who served as elders, deacons or missionaries with distinction were awarded with certificates that acknowledged their gifting (Langerman 1983, 125), without any further requirement of theological training. In practice the church recognised and acknowledged the Spirit's empowerment and equipment of an individual by formalising the person's ministry. Only after the first decade or two a few assemblies grew large enough to call and pay for a full-time leader. In the early days no one used any titles; members called each other 'brother' and 'sister' (Van der Spuy $1985,105-106)$. No one was required to obtain theological training, as George Fox (1624-1691), founder of the Religious Society of Friends (Quakers or Friends) emphasised (Punshon 1993, 537). The Pentecostal movement was founded on the principle that the believer who brought 'the message' did not need formal theological training but rather the guidance of the Spirit in interpreting and proclaiming the Bible. They also did not speak of a 'sermon' because the term reminded them too much of (Protestant) human endeavours to interpret the Bible; the Spirit provides the 
messenger with the words of the 'message'. No interest was shown in any formal academic theological reflection; members read the Bible at face value and believed what they read (Eybers, König and Stoop 1978, 174). The supposition was that the believer's study of the Bible, combined with the equipment of the spiritual gifts such as prophecy, words of wisdom and knowledge, as well as interpretation of tongues, would be adequate for the demands of the ministry (Nel 1993, 12).

The strong animosity against formal theological training can be interpreted as a reaction against the cold and formal exercise of worship that characterised learned reverends and churches that suspended many Pentecostal persons after their experience of the baptism with the Spirit (Du Plessis 1984, 213). Pentecostals shared the perception that learned reverends from traditional denominations did not succeed in mediating an encounter with God, while illiterate anointed laity within the Pentecostal movement preached the gospel powerfully, leading to conversions attested by signs and wonders, referring to 1 Corinthians 2:1-6 and 2 Corinthians 3:6 to justify their way of reasoning (Van der Spuy 1985,106$){ }^{1}$

The Pentecostal reaction to theological endeavours can also partly be understood as a reaction to the reviling, marginalisation and dismissal by some of the existing denominations, as well as the secular media that Pentecostal churches experienced for much of the first part of the twentieth century (Rance 2008, 14). Some Pentecostals probably hid their feelings of inferiority behind the self-assessment of the superiority of their spiritual qualities, based on their strong faith in the Word of God - excluding the necessity of theological reflection (Armstrong 2014, 276).

Pentecostal leaders from the 1940s found that their lack of theological training caused the community to be prejudiced, closing doors for them to serve on school boards, being elected as marriage officials and chaplains in the defence services, and taking part in religious broadcasts (Putter 2010,1). This led to the affirmative action of establishing Bible schools where training consisted of a basic knowledge of biblical data and the application of the contents of the Bible in the practice of daily ministry. As in Parham's Bible schools, the Bible was the only textbook studied in a literal sense. The Bible was read superficially and interpreted literally and prototypically $^{2}$ as far as possible, before it was pragmatically applied (Barr 1983, 27). It avoids any critical or systematic thinking that is associated with theological

1 Putter $(2009,194)$ argues that they never considered that the signs and wonders were in spite of, rather than because of their illiterateness. Pentecostals do not have much trouble in interpreting biblical texts that speak of God's miraculous activity, as some Western theologians and scholars have who use a scientific world view to interpret the Bible, because Pentecostals accept and expect that the supernatural could and would invade their world with miracles of healing, deliverance and provision (Menzies 2013, 22).

2 Much Old Testament data were interpreted as prototypes for New Testament events, and New Testament data as prototypes of what contemporary believers experience (Duffield and Van Cleave 1983, 19). 
or academic expertise, because such knowledge was regarded by Pentecostals as endangering the individual's faith and corrupting the church (Chan 2000, 45).

In their drive for acceptance and respectability (Anderson 1979, xi), and due to its revilement by a segment of the community, a crucial shift in perspective within the Pentecostal movement occurred gradually from the 1940s to the 1960s (Burger 1987, 307-310). The shift changed the perception that one only needs to be anointed with the Spirit to minister effectively, to the understanding that one needs a more solid theological training because of the challenges inherent to the ministry. This resulted in and coincided with the development of the professional pastorate (Burger 1987, 304-306; Menzies 2013, 129) and the resultant diminishment of the responsibilities of believers, changing them into spectators in the worship service and consumers of ministry. However, the idea became widespread among Pentecostals that tension would and should always stay between the working of the Spirit and academic training (Cronjé 1979, 46). Members often expressed the fear that theological knowledge might become a substitute for the immediate working of the Spirit, should the church make theological training compulsory to enter the ministry (Fee 1991, 84). The view was widespread that 'revelation knowledge' should be pursued without recourse to theological knowledge or scientific biblical exegesis, to serve as necessary standard against which any further revelation should be measured (Burger and Nel 2008, 389-394). For that reason the church chose purposefully for Bible school training that was 'spiritual', Bible-centred and Bible-oriented (Anderson and Pillay 1997, 236), with the Bible serving as the main (and in many instances, the only) textbook (Archer 2009, 92; Burger and Nel 2008, 393). This demonstrates the conservative attitude among Pentecostals that endeavours to preserve and retain the leading and guidance of the Spirit as experienced in the early days of the Pentecostal movement. Early Pentecostals thought in primitivistic and restorationist terms that their movement continued the (idealised) experience of the early church that was interrupted when church and state joined forces in the fourth century CE (Blumhofer 1989, 17-36; Wacker 1988, 196-219); in the same manner, later Pentecostals express their longing to experience the (idealised) early days of the Pentecostal movement (Hill 2016, 153; Liardon 1996, 17; Walsh 2004, 118).

From the 1970s a new mindset among Pentecostals led to new developments, including the change from 'Bible school' training to proper theological training and the establishment of theological colleges, later called seminaries (Chinappan 1993, 4; Reddy 1992, 160). The movement accepted that its leaders and pastors should be trained sufficiently to lead believers in a responsible manner to meet the demands of the day, leading to an integrated, Pentecostal liberal education (Turnage 2003, 21) and a pastorate consisting of full-time pastors (Burger and Nel 2008, 393). Eventually, theological training was made compulsory for anyone considering to 
enter the ordained ministry by most denominations, and as a result the gap between the 'clergy' and 'laity' broadened (Goff 2008, 91). ${ }^{3}$

\section{DEVELOPMENT OF PENTECOSTAL HERMENEUTICS}

It is hypothesised that Pentecostal hermeneutics developed alongside the movement's attitude towards theological training, and that hermeneutics and the attitude toward training influenced each other, as will now be demonstrated.

In the early days the Pentecostal movement was characterised by a charismatic, eschatologically-flavoured spirituality that also lay at the heart of its reading of the Bible (Kärkkäinen 1998, 77; Land 1993, 3), informed by experiential observation rather than theological reflection. The Pentecostal community lived in and from the eschatological presence of God, and an encounter with the supernatural was emphasised (Archer 1996, 64; Pluess 1993, 189). Pentecostalism was defined in terms of a personal experience of the Spirit's presence revealing Christ and his power to save and heal, empowering believers to witness and worship (Sandidge 1987, 41). Experience plays a role at the beginning of the hermeneutic process as presupposition and not only as verification (Stronstad 1992, 16). Pentecostal hermeneutics was informed by a supernatural, charismatic ethos as well as an intense eschatological expectation (Archer 1996, 65; 2009, 71), when Spirit baptism was interpreted as introducing the decisive final steps to the consummation that would usher in the kingdom of God. Pentecostals perceived that they were living in the time of the latter rain (Cargal 1993, 163; Synan 1971, 146).

The character of the movement was shaped by teaching and preaching purposefully, based on and explicating the Bible. It was also practically oriented, seeing that messages were preached not by theologians but mostly by blue collar workers (Byrd 1993, 203). As already explained, everybody participated in the preaching and through personal testimonies explicated messages they believed they had received from the Spirit; it was not limited to a few professionals (Archer 1996, 67). Everyone also participated in the message in terms of responding with acclamations of 'Amen' and 'Hallelujah' and even standing up and adding to the contents. When the altar call was given, interested people responded and believers shared with them. The purpose of the message was to reach the immediate needs of

3 The sketch of the development of theological training in the Pentecostal movement is illustrated by the history of the Apostolic Faith Mission of South Africa as explicated in Nel and Van Rensburg (2016, 1-8), where it is concluded that theological training in the AFM of SA has followed the same long and arduous journey over the past century that the Pentecostal Movement has generally followed. It started with the viewpoint that no training was necessary, because the Spirit would empower and reveal the gospel truths to believing witnesses. Gradually the movement recognised the need for better training in the form of the Bible school model. Eventually it realised the necessity of proper theological training, and university training was sought (Nel and Van Rensburg 2016, 8). 
listeners, therefore no time or energy was spent exegeting texts in a historical critical manner (Byrd 1993, 203-205).

The use of the Bible was characterised by the confession that the Bible is the inspired Word of God, given an authoritative role in determining doctrine and lifestyle as totally reliable, without recognising any historical distance between contemporary believers and the text (Duffield and Van Cleave 1983, 19-20). Texts were interpreted in terms of typology and allegory with an emphasis on immediate meaning and applied to the own context (Spittler 1985, 75-77). People had an encounter with God, and only in time started theologising about their experiences (Pluess 1993, 191). In providing theological explanations, Pentecostals employed the commonly shared epistemological presuppositions of the day, based upon a positivistic understanding of history (Pluess 1993, 192). Historical narratives in the Bible were viewed as credible versions of what happened, wie es eigentlich gewesen ist. The Bible was read and interpreted as literally as credibility could stand (Archer 1996, 65), at face value (Archer 1996, 66), and mostly without any critical reflection. The scopus applied in interpreting especially the New Testament, was the fourfold full-gospel pre-understanding of Jesus as Saviour, Baptiser, Sanctifier and soon coming King at the centre of charismatic life (Lewis 2016, 3; Menzies 1985, 13; Tomberlin 2010, 35-53); or the fivefold gospel of Christ as Saviour, Healer, Sanctifier, Baptiser and coming King, representing the belief among some Pentecostals that sanctification is a second experience apart from conversion and baptism with the Spirit (Lewis 2016, $3)$. The community shared in the interpretation of Scriptures under the leadership of the local preacher by contributing their thoughts about the message, while most of them were uneducated and ordinary folk (Spittler 1985, 75).

Early Pentecostals did their theologising in an oral manner, as is still the case in the Two Thirds World (Asamoah-Gyadu 2015, 75-77), representing the majority of inhabitants of the world. A systematic theology was not written down and published, but underlying their messages one finds such a systematic breakdown of biblical data, based on a narrative approach. Texts were read as a model for the believer's life, 'without angst about the miraculous or how it all fits into complex theological systems' (Menzies 2013, 23-24). This enabled the message to be grasped by people in pre- or semi-literate, more experiential as well as more cognitive cultures. Knowledge of God was perceived as relational and not merely informational, and from the immediate experience orality was regarded as better serving the purpose of witnessing to God's work (Ellington 1996, 26; Moltmann and Kuschel 1996, viii). Orality was (and still is), after all, the primary mode of communication in the faith community. Oral experiential theologising also allows the uneducated to participate (Ellington 1996, 26) and enables them to contribute to God's work and build up the church, the body of Christ (Eph 4:12). Moreover, their stories and orations of God's intervention in their lives still capture the imagination of their listeners. 
At first, Pentecostals existed on the fringes of society and they were reviled, rejected and even persecuted by other churches and their members. As indicated above, from the 1940s they sought for ways to be accepted that might improve their status, leading them to seek alliance with the evangelical segment of the Protestant church. And although evangelicals of a fundamentalist conviction did not accept Pentecostal theology, they did not turn the Pentecostals down when they were courted. Many American Pentecostal groups, especially predominantly white assemblies, were allowed to participate in the National Association of the Evangelicals (NAE) (Jacobsen 1999, 90-107). It gave the evangelicals more power when growing numbers of Pentecostals associated with their position and for Pentecostals it meant an association with and acceptance by respected company (Kärkkäinen 1998, 80). In this era and as a result of the association with the evangelicals, the movement established Bible schools to train pastors in the evangelicals' fundamentalistliteralistic way of reading the Bible (Lewis 2016, 4). ${ }^{4}$

The price the Pentecostals had to pay for this association was that they eventually accepted the fundamentalist-dispensationalist hermeneutic of the evangelicals with their literalism and doctrine of the inerrancy of Scripture (Daniels 1999, 247; Lewis 2016, 5; Synan 1988, 324-327). ${ }^{5}$ Fundamentalism originated as a critique on modernism and especially the (liberal) historical critical study of the Bible that was perceived as endangering the survival of the church (Patte 1976, 7). Pentecostals also shared with the evangelicals a strong anti-intellectualism which persists in a modified form even to the present day (Satyavrata 1999, 208, 219).

Modernism and fundamentalism (as a critique on modernism) share a key epistemological presupposition, of objectivity brought into service of a historicist view of meaning (Bosch 1992, 342-345; Cargal 1993, 163-187), providing in conservatives' overriding need for solid certainties and knowledge that stands firm. Cargal (1993, 167-168) notes that Pentecostals as well as evangelicals should have countered the objective categories with a supernatural reality that they believe in; however, they shared in an uncritical manner the positivistic epistemology of the Enlightenment with modernism (cf. Jacobsen 1999, 90-107; Robeck 1988, 635).

Pentecostals who ventured into the academy since the 1970s, the last era indicated in this study of the development of theological training with its establishment of theological colleges and seminaries, tended to still align themselves with the evangelicals (Lewis 2016, 7). They maintained a commitment to the reliability of Scripture, even though they eventually and eclectically adopted some of the methods

4 This era also saw the division of classical Pentecostals into Holiness Pentecostals, 'Baptistic' Pentecostals and Oneness Pentecostals (Daniels 1999, 238-239; Lewis 2016, 4).

5 When Pentecostals started utilising fundamentalist evangelical textbooks it had some unforeseen results, such as accepting the more formal liturgy in worship services and diminishing the historical role that women previously played in Pentecostal ministry (Daniels 1999, 235; Poloma 1989, 119, 241-243). 
of historical criticism (Fee 2002, 3). In the process they emphasised the historical contexts of biblical narratives at the cost of a focus on the intent of the 'inspired' authors (Cargal 1993, 164) and an emphasis on the immediacy of the text, its multiple meanings and relevance for here and now. However, this led to a growing divergence between Pentecostal pastors and theologians (Cargal 1993, 179; Lederle 1988, 162; Lewis 2016, 10), with most members and pastors reading the Bible in a more fundamentalist-literalist way as Pentecostals had been doing for the past six decades.

It is important to note that a fundamentalist understanding of Scripture is not an integral part of the historical Pentecostal heritage (Hollenweger 1996, 6; Lewis $2016,8)$ but it was allowed into Pentecostal churches as a result of the alignment with evangelicals. As a matter of fact, early Pentecostals did not ground the authority of Scripture on the bedrock of inerrancy or any other doctrine, but rather on the personal experience of an encounter with God, as Ellington $(1996,17)$ convincingly argues. The basis for the process of forming doctrine among Pentecostals was the experience of the community of faith (Ellington 1996, 17), interpreting the Bible from their communal encounter with God through his Spirit (Sheppard 1994, 140). This does not imply that Scripture is not the norm for faith and practice, but that belief is not based on doctrine handed down in tradition but rather on repeated observations of the ways in which God utilises Scripture interactively (Ellington 1996, 21).

Inerrancy of the Bible was not the basis in early Pentecostal hermeneutics, but the Bible was perceived as inspired and preserved by the Spirit with the express purpose to illuminate, teach and transform the lives of contemporary believers. The Spirit who inspired and preserved the Scriptures, illuminates, teaches, guides, convicts and transforms through that Word today, so that Scripture only becomes effective as Spirit-Word (Land 1993, 94). In other words, the Bible becomes the Word because of the Spirit's ministry (Land 1993, 100) and the Spirit's authority comes before the authority accorded to the Bible (Land 1993, 106; Welker 1996, 76), leading to the risk of subjectivism. That is the reason why Pentecostals do not make a sharp distinction - like evangelicals - between 'inspiration' of the original text and 'illumination' of the read text by the Spirit (Henry 1979, 500). A modernday believer can experience existentially what the earliest apostles experienced through the working of the same Spirit and accompanied by the same charismatic phenomenology that characterised also the earliest church (Ervin 1981, 22).

An important aspect of original Pentecostal hermeneutics was its emphasis on Lukan narratives (Ervin 1984; 1985, 23-35; Stronstad 1984, 39). Even though it is a generalisation, there is truth in the statement that magisterial Protestantism tends to read the Bible through the lens of Pauline theology, while Pentecostalism reads the New Testament through Lukan eyes, with a special emphasis on Luke's book of Acts as the narrative of the history of the early church (Menzies 2013, 26, 121). The 
Lukan perspective of the Holy Spirit, in contradistinction to Paul's, continues to be a crucial focus for Pentecostal scholars (Hollenweger 1988, 336; Mittelstadt 2004, 2).

The turn from Paul to Luke implies, according to Stott $(1976,15)$, a shift within Pentecostal exegesis and hermeneutics from narrative to didactic texts in the Scriptures used to define Pentecostals' theology and praxis. 'Pentecostals operate on a hermeneutic which affirms that normative beliefs and practices may properly be derived from narratives on the basis of historical precedent' (Noel 2007, 150). Stott describes this as a major flaw because narrative texts do not lend themselves easily to forming theological conclusions, as is the case with didactic texts. However, Pentecostals read the narratives in Acts with a specific aim in mind, as a precedent that needs to be replicated in the life of contemporary believers (Archer 2009, 140-156). They do not primarily define doctrine from the narratives but use the narratives as a model for what they expect to experience themselves, in their encounter with the Spirit. Their 'subjectivising hermeneutic' requires that the events of salvation be re-enacted in contemporary believers' lives (Olson 1999, 491). For this reason, knowledge about the Bible (theology or doctrine) plays a subservient role; what is important is that contemporary believers experience what the biblical narrative describes. Even the events described in the Old Testament are supposed and expected to happen in the lives of contemporary believing readers, with the exodus, wilderness experiences, crossing of the Jordan into the Promised Land and its conquest, and the exilic experience interpreted as stages in the pilgrimage from conversion from the slavery of sin to eternal life in the promised land (Dayton 1987, 24; Neve 2011, 35). And in the New Testament the baptism with the Spirit on the Day of Pentecost is seen as an experience available to all believers as a requirement to be empowered, with the sign of 'speaking with other tongues as the Spirit gives utterance' (Acts 2:4) (Menzies 1971, 9). ${ }^{6}$ Pentecostals' immediate experience and non-systematic tradition contrast with the systematising tradition found in Aquinas as well as in most Protestants (Campos 1989, 1, 4-5).

In recent years hermeneutics has been a 'hot topic for Pentecostals' (Kärkkäinen $1998,76)$ in seminaries and academic work, leading to widespread discussions and several publications. However, biblical interpretation in the pews and, to a large extent, in the pulpit, seems to go on as if nothing has happened, as has been explained. Pentecostal theologians at seminaries are tackling the issues and challenges in terms of approaching and appropriating Scripture for our day and in terms of the hermeneutics of the early Pentecostal movement, as demonstrated by a short discussion of some of the more important results (Lewis 2016, 9).

6 Pentecostals recognise the difference between the original experience depicted in Acts 2:5-6 where the different languages were recognised by people from different countries (xenolalia) and the modern-day believer's experience of speaking in unknown tongues (glossolalia) that requires another charisma, of interpretation, before it makes sense, and which probably coincides with that of the believers in Corinth (according to 1 Cor. 14:13). 
A contemporary Pentecostal hermeneutical approach can by way of summary be explained in terms of four principles. In the first place, it is important to note that the Bible as such is not the object of Pentecostals' interpretation but the Spirit's communication about what the believer reads in the Bible, is deemed as the revelation of God for the contemporary believer. The supposition is that the Holy Spirit communicates with believers in ways that surpass human reason. This implies that the Bible is supposed to become a living word that interprets the believer (Moore 1987, 12-13) and leads to a sense of connection with the text that encourages believers to allow the narrative to shape their lives, hopes, dreams and imagination (Menzies 2013, 21-22). The Spirit works and speaks through the Bible in ways that cannot be predicted or determined, just as he also works and speaks in many other ways to reveal Christ and his Word.

In the second place, what is important is that the believer stands in a relationship with God, leading to knowledge of God based on the Bible, but then knowledge mediated through a specific encounter with God related to a unique situation in the life of the believer (Loder 2000, 40). For this reason, knowledge about God found in the Scripture should be combined with practical experience with God. The result of the believer's interaction with the Bible is therefore never intellectual knowledge about God, his character and will, but rather a change in character and will of the believer. Dealing with the Bible is not synonymous with gathering information about the Bible. The goal of any attempt to study the Bible is to know God; it is not only to gather information about God. This implies a distinction between a 'correct reading' that leads to knowledge about God based on finding the original intention of the biblical author by means of exegetical methods, and a 'creative reading' of the Bible that leads to an explanation of how a given passage can be put into practice today (Alkier 2005, 5; Autry 1993, 33). The latter, a creative reading, underlines the immediacy in Pentecostal reading and interpreting of the Bible (Noel 2007, 268).

Thirdly, in Pentecostal hermeneutics the priesthood and prophethood of all believers are imperative in dealing with the Bible, implying that every believer has free access to the Bible and in theory contributes to its interpretation (Stronstad 1999, 114-116); as happens for instance in a house church where a group of believers discuss the contents of a scriptural passage. All believers are called to witness to the truth of the Bible found in their encounter with God (Stronstad 1999, 113).

Lastly, the community of faith plays a significant role in dealing with the Bible under the support of the Spirit. Archer (1996, 78-79; 2009, 212-253) uses the meeting of church leaders in Acts 15 and its use of the Old Testament as a parable to define the process of interpretation through the interaction between the given community of faith, the activity of the Spirit, and Scripture, within the context of life of that respective community. These components have to be brought into dialogue with each other, he argues. The hermeneutical process is solemnised when the Spirit draws the attention of the community of believers to the relevance of biblical passages for 
the life context of a specific church (Acts 15:16-18, 28). In this way, the church exercises a corrective influence to prevent individual interpretation that may lead to heretical teachings. 'New' theological and spiritual insights are tested by the group of believers that serves as the body of Christ on earth (Noel 2007, 149). The last remark is important because Pentecostal hermeneutics allows - by way of definition with its 'pietistic, experiential, heartfelt approach to interpretation' - for subjectivistic impressions that may (and in the past have) become dangerous (Noel 2007, 209).

Cargal (1993, 186-187) takes the argument a step further by stating that Pentecostalism acknowledges the significant role of the Bible reader when dealing with Scripture, realising that there are many different levels of meaning in a text and allowing various equally accepted interpretations for one passage; and that readers may dialogue with the text in different ways based on their personal experience (Noel 2007, 20-21). These features show affinities with some postmodern approaches, placing Pentecostal hermeneutics within the postmodern paradigm (Martin 2013, 38). However, the warning of Johns (1995, 84-85) is timely, that Pentecostal hermeneutics should not be allowed to happen within the frame of any other Weltanschauung than a Pentecostal one, where the core of truth lies in an encounter with God which leads to life transformation in humans and enables them to see all of reality in a new perspective, in the process of reading the Bible (Martin 2013, 59-60). Pentecostal theologians should view Scripture as a fixed reference point for the encounter with God; this forms the core of Pentecostal identity. The Pentecostal understanding of truth may never be made compatible with contemporary postmodern pluralism (Johns 1995, 75).

By way of conclusion, it is not possible to speak of one fixed nature of Pentecostal biblical interpretation (Becker 2004, 34). It consists rather of different aspects, of which historical-grammatical exegesis, the significance of the community of faith, the importance of the Holy Spirit with respect to inspiring, enlightening and illuminating authors and readers, and elements of new hermeneutical approaches with their emphasis on the important role of the reader in the process of interpretation, are some of the most important. The Bible is perceived as inspired and preserved by the Spirit and illuminated, taught and transformed in the lives of contemporary believers. The Bible becomes the Word because of the Spirit's ministry.

\section{CONCLUSION}

A historical survey of the Pentecostal movement shows that its attitude toward theological training as well as its hermeneutical journey can be described in terms of three phases: An early era covers the first four decades where the Bible was read at face value and believed as though it describes the expectation that present-day readers should have, and no theological training was deemed necessary for ministry. The next era started in the 1940s when, in their quest for acceptance, Pentecostals entered into 
a partnership with evangelicals and accepted their fundamentalist-dispensationalist hermeneutics with its literalist practices and doctrine of the inerrancy of Scripture. Today this hermeneutic determines how most Pentecostals still read the Bible. From the seventies a third era emerged when Pentecostals became convinced of the need for better training and established theological colleges (and eventually, seminaries) where Pentecostal theology was studied. This eventually led to a new interest in the original hermeneutics that characterised the Pentecostal movement at its foundation and in the movements that preceded it. The developing hermeneutic, resulting in a growing divergence between Pentecostal pastors and theologians, has stated affinities with the original Pentecostal hermeneutic and it is characterised by an emphasis on the historical contexts of biblical narratives at the cost of a focus on the intent of the 'inspired' authors and an emphasis on the immediacy of the text, its multiple meanings and relevance for here and now.

\section{REFERENCES}

Alkier, S. 2005. From text to intertext: Intertextuality as a paradigm for reading Matthew. Hervormde Teologiese Studies 61(1\&2): 1-18.

Anderson, A.H. and Pillay, G.J. 1997. The segregated spirit: The Pentecostals. In Christianity in South Africa: A political, social, and cultural history, 227-241. Edited by R. Elphick and R. Davenport. Berkeley: University of California Press.

Anderson, R.M. 1979. Vision of the disinherited: The making of American Pentecostalism. New York: Oxford University Press.

Archer, K.J. 1996. Pentecostal hermeneutics: Retrospect and prospect. Journal of Pentecostal theology 8: 63-91.

Archer, K.J. 2009. A Pentecostal hermeneutic: Spirit, scripture and community. Cleveland: CPT.

Armstrong, K. 2014. Fields of blood: Religion and the history of violence. London: Bodley Head.

Asamoah-Gyadu, J.K. 2015. Sighs and signs of the Spirit: Ghanaian perspectives on Pentecostalism and renewal in Africa. Regnum Studies in Mission. Oxford: Regnum.

Autry, A.C. 1993. Dimensions of hermeneutics in Pentecostal focus. Journal of Pentecostal Theology 3: 29-50.

Barr, J. 1983. Holy Scripture: Canon authority criticism. Oxford: Clarendon.

Becker, M. 2004. A tenet under examination: Reflections of the Pentecostal hermeneutical approach. Journal of the European Pentecostal Theological Association 24: 30-48.

Blumhofer, E.L. 1989. The Assemblies of God: A chapter in the story of American Pentecostalism, Vol. 1 - to 1941. Springfield: Gospel Publishing.

Bosch, D. 1992. Transforming mission: Paradigm shifts in theology of mission. Maryknoll: Orbis.

Burger, I.S.V.D.M. 1987. Geloofsgeskiedenis van die Apostoliese Geloofsending van Suid-Afrika 1908-1958. Gepubliseerde DD verhandeling, Universiteit van Pretoria. Johannesburg: Gospel Publishers. 
Burger, I. and Nel, M. 2008. The fire falls in Africa: A history of the Apostolic Faith Mission of South Africa. Vereeniging: CUM.

Byrd, J. 1993. Paul Ricoeur's hermeneutical theory and Pentecostal proclamation. Pneuma 15(2): 203-214.

Campos, B.L. 1989. From experience to Pentecostal theology. Unpublished paper presented to the Encuentro Pentecostal Latinoamericano, Buenos Aires, Argentina. Tr. by J. Beaty and S.J. Land.

Cargal, T. 1993. Beyond the fundamentalist-modernist controversy: Pentecostals and hermeneutics in a postmodern era. Pneuma 15(2): 163-187.

Chan, S. 2000. Pentecostal theology and the Christian spiritual tradition. JPTSup 21. Sheffield: Sheffield Academic Press.

Chandomba, L. 2007. The history of the Apostolic Faith Mission and other Pentecostal Missions in South Africa. Keynes: AuthorHouse.

Chinappan, M. 1993. In Covenant Bible College, Durban. Brochure 1983-1993. Privately published.

Cronjé, F.H.J. 1979. Die AGS Teologiese Kollege. In AGS Werkersraadverslagbundel. Johannesburg: AGS.

Daniels, D. 1999. Everyone bids you welcome: A multicultural approach to North American Pentecostalism. In Globalization of Pentecostalism, 222-252. Edited by M. Dempster, B, Klaus and D. Petersen, Irvine: Regnum.

Dayton, D. 1987. Theological roots of Pentecostalism. Peabody, MA: Hendrickson.

Du Plessis, L. 1984. Pinkster panorama: 'n Geskiedenis van die Volle Evangelie-Kerk van God in Suidelike Afrika. Gepubliseerde DD verhandeling, Universiteit van Pretoria. Irene: VEK.

Duffield, G.P. and Van Cleave, N.M. 1983. Foundations of Pentecostal theology. Los Angeles: Foursquare.

Ellington, S.A. 1996. Pentecostals and the authority of Scriptures. Journal of Pentecostal theology 4(9): 16-38.

Erasmus, L.J. 1996. Theological education in the Apostolic Faith Mission of South Africa. Unpublished DTh dissertation, University of South Africa.

Ervin, H.M. 1981. Hermeneutics: A Pentecostal option. Pneuma 2(2): 3-23.

Ervin, H.M. 1984. Conversion-initiation and the baptism in the Holy Spirit. Peabody: Hendrickson.

Ervin, H.M. 1985. Hermeneutics: A Pentecostal option. In Essays on apostolic themes, 23-35. Edited by P. Ebert. Peabody: Hendrickson.

Eybers, I.B., König, A. and Stoop, J.A. 1978. Introduction to theology. Pretoria: NG Kerkboekhandel.

Fee, G.D. 1991. Gospel and Spirit: Issues in New Testament hermeneutics. Grand Rapids: BakerAcademic.

Fee, G.D. 2002. New Testament exegesis: A handbook for students and pastor. (3 ${ }^{\text {rd }}$ edition). Atlanta: Westminster John Knox.

Garrard, D. 2009. Leadership versus the congregation in the Pentecostal/charismatic movement. Journal of the European Pentecostal and Theological Association 29(2): 90-103. 
Goff, C.W. 2008. Measuring the clergy/laity gap and its effect on church health and outreach. Eisenhower: ProQuest.

Hayford, J.W. 2006. The charismatic century: The enduring impact of the Azusa Street Revival. New York: Warner Faith.

Henry, C.F. 1979. God, revelation, and authority: God who speaks and shows. Waco: Word.

Hill, S.E. 2016. 'A seed-sowing time': M.M. Pinson's Pentecostal paths in Alabama. The Alabama Review 69(2): 132-163.

Hollenweger, W.J. 1988. The Pentecostals. London: SCM.

Hollenweger, W.J. 1996. From Azusa Street to Toronto phenomenon: Historical roots of Pentecostalism. Concilium 3: 3-14.

Hunter, H.D. 2013. Introduction: Global Pentecostals are not 'Protestants' and are not 'Western'. In The many faces of global Pentecostalism, 1-5. Edited by H.D. Hunter, H.D. and N. Ormerod. Cleveland: CPT.

Jacobsen, D. 1999. Knowing the doctrines of the Pentecostals: The scholastic theology of the Assemblies of God, 1930-55. In Pentecostal currents in American Protestantism, 90-107. Edited by E. Blumhofer, R. Spittler and G. Wacker. Urbana: University of Illinois Press.

Johns, J.D. 1995. Pentecostalism and the postmodern worldview. Journal for Pentecostal Theology 7:73-96.

Kärkkäinen, V-M. 1998. Pentecostal hermeneutics in the making: On the way from fundamentalism to postmodernism. Journal of the European Theological Association 18: 76-115.

Land, S.J. 1993. Pentecostal spirituality: A passion for the kingdom. Cleveland: CPT.

Langerman, J.L. 1983. Apostolic Faith Mission of South Africa: A revitalization of the theological concepts of church ministry. Unpublished DMin dissertation, Fuller Theological Seminary.

Lederle, H. 1988. Treasures old and new: Interpretation of the Spirit baptism in the charismatic renewal movement. Peabody: Hendrickson.

Letson, H. 2007. Pentecostalism as a paradigm shift: A response to Hans Kung's paradigmatic model. Journal of the European Pentecostal Theological Association 27(2):104-117.

Lewis, P.W. 2016. Reflections of a hundred years of Pentecostal theology. Cyberjournal for Pentecostal-charismatic research. Paper presented at the $9^{\text {th }}$ Annual Willieam Menzies Lectureship in January, 2001 at Asia Pacific Theological Seminary in Baguio, Phillipines, 1-25. http://www.pctii.org/cyberj/cyberj12/lewis.htm\#_ftn1 (accessed on 31 January 2016).

Liardon, R. 1996. God's generals: Why they succeeded and why some failed. New Kensington: Whitaker.

Loder, A.T. 2000. An examination of the classical Pentecostal doctrine of the baptism in the Holy Spirit in light of the Pentecostal position on the sources of theology. MDiv dissertation, Providence Theological Seminary.

Martin, D. 2013. Pentecostalism: An alternate form of modernity and modernization? In Global Pentecostalism in the $21^{\text {st }}$ century, 37-62. Edited by R.W. Hefner. Bloomington: Indiana University Press.

McClung, G. 2012. Try to get people saved: Azusa Street 'missiology'. In Azusa Street and beyond: Missional commentary on the global Pentecostal/charismatic movement, 1-21 (revised edition). Edited by G. McClung. Alachua: Bridge-Logos. 
Melton, J.G. 2016. Pentecostalism. http://www.britannica.com/topic/Pentecostalism (accessed on 30 January 2016).

Menzies, R.P. 2013. Pentecost: This story is our story. Springfield: GPH.

Menzies, W. 1971. Anointed to serve. Springfield: Gospel Publishing.

Menzies, W. 1985. The methodology of Pentecostal theology: An essay on hermeneutics. In Essays on apostolic themes, 1-14. Edited by P. Elbert. Peabody: Hendrickson.

Menzies, W. 2010. The language of the Spirit: Interpreting and translating charismatic terms. Cleveland: CPT.

Mittelstadt, M.W. 2004. The Spirit and suffering in Luke-Acts: Implications for a Pentecostal theology. London, New York: T\&T Clark.

Moltmann, J. and Kuschel, K.J. (eds). 1996. Preface. Concilium 3:i-viii.

Moore, R.D. 1987. A Pentecostal approach to Scripture. Seminary Viewpoint 8(1): 4-14.

Nel, M. 1993. ' $n$ Man deur God in 'n hoek gedryf. Johannesburg: John G. Lake Stigting.

Nel, M. and. J. van Rensburg, F. 2016. Integrating spirituality and rationality the long and arduous journey of the historical development of theological training in the Apostolic Faith Mission of South Africa. In die Skriflig 50(2): a1943. http://dx.doi. org/10.4102/ids.v50i2.1943

Neve, L.R. 2011. The Spirit of God in the Old Testament. Centre for Pentecostal Theology Studies Classics Series. Cleveland: CPT.

Noel, D.T. 2007. Pentecostal and postmodern hermeneutics: Comparisons and contemporary impact. DTh dissertation, University of South Africa.

Olson, R.E. 1999. The story of Christian theology: Twenty centuries of tradition and reform. Leicester: Apollos.

Patte, D. 1976. What is structural exegesis? Guides to Biblical scholarship: New Testament Series. Philadelphia: Fortress.

Pluess, J-D. 1993. Azusa and other myths: The long and winding road from experience to stated belief and back again. Pneuma 15(2): 189-201.

Poloma, M. 1989. The Assemblies of God at the crossroads. Knoxville: University of Tennessee Press.

Punshon, J. 1993. Quakerism. In The Blackwell Ensyclopedia of modern Christian thought, 536538. Edited by A.E. McGrath. Oxford: Blackwell.

Putter, A.P.J. 2009. Aucklandpark Teologiese Seminarium: Die hartseer verlede en uitdagings in die nuwe millennium. Studia Historiae Ecclesiasticae 35(Supplement): 193-210.

Putter, A.P.J. 2010. Riglyne vir voortgesette teologiese opleiding: Uitdagings vir die AGS-kerk. Verbum et Ecclesia 31(1), Art. \#417, 8 pp. DOI: 10.4102/ve.v31i1.417

Rance, D. 2008. Fulfilling the apostolic mandate in apostolic power: Seeking a Spirit-driven missiology and praxis. Paper presented at inaugural address as J. Philip Hogan Professor of World Missions at Assemblies of God Theological Seminary, Springfield, Missouri. https:// www.agts.edu/faculty/faculty_publications/lectures/rance_delonn_inaugural_lecture.pdf (accessed on 4 February 2016).

Reddy, D.C. 1992. The Apostolic Faith Mission of South Africa with special reference to its rise and development in the 'Indian' community. Unpublished MTh dissertation, University of Durban-Westville. 
Robeck, C.M. 1988. National Association of Evangelicals. In Dictionary of Pentecostal and charismatic movements, 634-636. Edited by S.M. Burgess and G.B. McGee. Grand Rapids: Zondervan.

Sandidge, J.L. 1987. Roman Catholic-Pentecostal dialogue (1977-1982): A study in developing ecumenism. Studien zur interkulturellen Geschichte des Christentums, 144. Frankfurt am Main: Peter Lang.

Satyavrata, I. 1999. Contextual perspectives on Pentecostalism as a global culture: A South Asian view. In Globalization of Pentecostalism, 203-221. Edited by M. Dempster, B. Klaus and D. Petersen. Irvine: Regnum.

Sheppard, G.T. 1994. Biblical interpretation after Gadamer. Pneuma 16(1): 121-145.

Spittler, R.J. 1985. Scripture and the theological enterprise: A view from the big canoe. In The use of the Bible, 71-81. Edited by R.K. Johnston. Atlanta: John Knox.

Stott, J.R.W. 1976. Baptism and fullness: The work of the Holy Spirit today (revised edition). Downers Grove: InterVarsity.

Stronstad, R. 1984. The charismatic theology of St. Luke: Trajectories from the Old Testament to Luke-Acts ( $2^{\text {nd }}$ edition). Grand Rapids: BakerAcademic.

Stronstad, R. 1992. Pentecostal experience and hermeneutics. Paraclete 26(1):14-30.

Stronstad, R. 1999. The prophethood of all believers: A study in Luke's charismatic theology. Cleveland: CPT.

Synan, V. 1971. The Holiness-Pentecostal movement in the United States. Grand Rapids: Eerdmans.

Synan, V. 1988. Fundamentalism. In Dictionary of Pentecostal and charismatic movements, 324327. Edited by S.M. Burgess and G.B. McGee. Grand Rapids: Zondervan.

Synan, V. 1997. The Holiness-Pentecostal tradition: Charismatic movements in the twentieth century ( $2^{\text {nd }}$ edition $)$. Grand Rapids: Eerdmans.

Tomberlin, D. 2010. Pentecostal sacraments: Encountering God at the altar. Cleveland: Center for Pentecostal Leadership and Care.

Turnage, M. 2003. The early church and the axis of history and Pentecostalism: Facing the $21^{\text {st }}$ century: Some reflections. Journal of the European Pentecostal Theological Association 23: 4-29.

Van Der Spuy, M.A. 1985. Die spanning tussen vryheid en formalisering ten opsigte van die liturgiese verskuiwinge binne die Apostoliese Geloof Sending van Suid-Afrika. Ongepubliseerde MTh verhandeling, Universiteit van Suid-Afrika.

Wacker, G. 1988. Playing for keeps: The primitivist impulse in early Pentecostalism. In The American Quest for the Primitive Church, 196-219. Edited by R.T. Hughes. St Louis: Urbana.

Walsh, T. 2004. 'A sane people, free from fads, fancies and extravagances': Rhetoric and reality of collective worship during the first decade of the Pentecostal movement in Britain. Journal of the European Pentecostal Theological Association 24: 101-119.

Welker, M. 1996. Word and Spirit, Spirit and Word: A Protestant response. Concilium 3: 52-79.

Whitehouse, W.A. 1953. The modern discussion of eschatology. In Eschatology, 63-90. Edited by W. Manson et al. Scottish Journal of Theology Occasional Papers 2. Edinburgh: Oliver and Boyd. 